\title{
Deep plant-derived carbon storage in Amazonian podzols
}

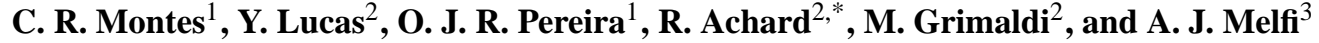 \\ ${ }^{1}$ NUPEGEL, CENA, Universidade de São Paulo, Piracicaba, Brazil \\ ${ }^{2}$ PROTEE, Université du Sud Toulon-Var, La Garde, Toulon, France \\ ${ }^{3}$ NUPEGEL, ESALQ, Universidade de São Paulo, Piracicaba, Brazil \\ *now at: INERIS, Aix-en-Provence, France
}

Received: 22 September 2010 - Published in Biogeosciences Discuss.: 19 October 2010

Revised: 6 January 2011 - Accepted: 7 January 2011 - Published: 18 January 2011

\begin{abstract}
Equatorial podzols are soils characterized by thick sandy horizons overlying more clayey horizons. Organic matter produced in the topsoil is transferred in depth through the sandy horizons and accumulate at the transition, at a depth varying from 1 to more than $3 \mathrm{~m}$, forming deep horizons rich in organic matter (Bh horizons). Although they cover great surfaces in the equatorial zone, these soils are still poorly known. Studying podzols from Amazonia, we found out that the deep Bh horizons in poorly drained podzol areas have a thickness higher than $1 \mathrm{~m}$ and store unexpected amounts of carbon. The average for the studied area was $66.7 \pm 5.8 \mathrm{kgC} \mathrm{m}^{-2}$ for the deep Bh and $86.8 \pm 7.1 \mathrm{kgC} \mathrm{m}^{-2}$ for the whole profile. Extrapolating to the podzol areas of the whole Amazonian basin has been possible thanks to digital maps, giving an order of magnitude around $13.6 \pm 1.1 \mathrm{PgC}$, at least $12.3 \mathrm{PgC}$ higher than previous estimates. This assessment should be refined by additional investigations, not only in Amazonia but in all equatorial areas where podzols have been identified. Because of the lack of knowledge on the quality and behaviour of the podzol organic matter, the question of the feedback between the climate and the equatorial podzol carbon cycle is open.
\end{abstract}

\section{Introduction}

In spite of the great areas the tropical podzols cover worldwide - more than $140000 \mathrm{~km}^{2}$ in Amazonia (Bernoux et al., 2002; Batjes and Dijkshoorn, 1999) - and the fact that they have been recognized as early as 1941 (Richards, 1941), these systems are still incompletely known. Most of the

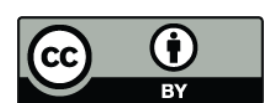

Correspondence to: C. R. Montes

(crmlauar@usp.br) knowledge about their genesis and dynamics comes from studies conducted in French Guyana (Boulet et al., 1982; Lucas et al., 1987; Veillon, 1991), Brasil (Lucas et al., 1984, 1988, 1996; Chauvel et al., 1987; Dubroeucq and Volkoff, 1988, 1998; Bravard and Righi, 1989, 1990; Volkoff et al., 1990; Righi et al., 1990; Dubroeucq et al., 1991; Horbe et al., 2004; Nascimento et al., 2004; Montes et al., 2007; PatelSorrentino et al., 2007; Bardy et al., 2007, 2008; Fritsch et al., 2009) and Peru (Veillon and Soria-Solano, 1988). Similar systems were also briefly described in Africa (Brammer, 1973; Schwartz, 1988) and in Borneo (Brabant, 1987).

These systems have been reported on both crystalline or sedimentary rocks. They can develop when soil solutions turn hyper-acidic, due to very low alkali or alkaline-earth cations in the soil solution, turning negative the alkaline reserve (Grimaldi and Pedro, 1996) or when the soil material is sandy enough to allow the leaching of $\mathrm{Al}$ - and $\mathrm{Fe}$-organic matter complexes, resulting in the dissolution of clay minerals, Al-hydroxides and Fe-oxides or Fe-oxyhydroxides (Lucas, 2001). When initiated, the development of the sandy eluviated horizons (white sand horizons) is favoured by a positive feed-back and the podzols laterally develop at the expense of the ferralsols (Lucas et al., 1984; Lucas and Chauvel, 1992). Where the time of evolution of such systems was sufficient, large areas of the landscape are covered by podzols (Dubroeucq et Volkoff, 1998). Aquifers in the white sands frequently reach the topsoil and are rich in dissolved organic matter (DOM). Measured values of dissolved organic carbon (DOC) in the literature range from 25 to $38 \mathrm{mg} \mathrm{L}^{-1}$ (Patel-Sorrentino et al., 2007), when the mean value at the mouth of the Rio Negro, which drains extensive podzol areas in Amazonia, is estimated around $8.5 \mathrm{mg} \mathrm{L}^{-1}$ (Tardy et al., 2009).

Published by Copernicus Publications on behalf of the European Geosciences Union. 
The DOM moves freely through sandy materials, but adsorbs on surfaces of fine minerals as clays, oxides or (oxi)hydroxides (Davis, 1982; Kaiser and Zech, 2000). As a consequence, when the DOM-rich groundwater flowing in the white sands comes in a more clayey material, as the horizons immediately underlying the white sands, it leaves much of its DOM which adsorbs at the transition, forming a horizon rich in organic matter (Bh) (Lucas et al., 1996). The aquifers in the more clayey materials have a low DOC content, typically lower than $2 \mathrm{mg} \mathrm{L}^{-1}$ (Patel-Sorrentino et al., 2007).

As a result, podzols can play an important role in global carbon dynamics. Considering the Amazonian basin, they provide approximately a tenth of the $0.13 \mathrm{Pg}$ of carbon annually exported to the Atlantic ocean (Tardy et al., 2009). The podzols can also store large amounts of carbon in their upper horizons and in the deep $\mathrm{Bh}$ horizons. In flat podzols areas, the frequently waterlogged upper horizons can present turflike material over a thickness greater than $30 \mathrm{~cm}$, the soils are then classified as histosols. The carbon stored in the podzols $0-0.3 \mathrm{~m}$ upper horizons was estimated around $5.5 \mathrm{kgC} \mathrm{m}^{-2}$ by Batjes et Dijskhoorn (1999) and 6-7 $\mathrm{kgC} \mathrm{m}^{-2}$ by Bernoux et al. (2002). The former authors distinguished the histosols from the podzols, evaluating the carbon stored in the $0-1 \mathrm{~m}$ upper horizon as $9 \mathrm{kgC} \mathrm{m}^{-2}$ for the podzols and $72.4 \mathrm{kgC} \mathrm{m}^{-2}$ for the histosols. These values, however, do not take in account possible deep Bh and are based on a small collection of studied profiles, less than 30 podzol profiles for the whole Amazonia.

Four detailed studies have considered the deep Bh horizons of Amazonian podzols (Lucas et al., 1984; Veillon and Soria-Solano, 1988; Veillon, 1991; Nascimento et al., 2004). As their objectives were to study the genesis and dynamics of ferralsol-podzol systems, they were conducted in relatively well-drained areas of transition between ferralsols and podzols. They showed that the deep podzol Bh's had a thickness increasing when going from the transition towards the podzolic, marshy areas. Their maximum $\mathrm{C}$ content calculated from the data given in the studies were 8, 15, 13 and $25 \mathrm{~kg} \mathrm{~m}^{-2}$, respectively, which suggests that marshy areas can store large quantities of carbon in depth. Existing studies in such areas, however, are scarce and limited to the upper horizons, due to the difficulties for observing deep horizons because of the collapse of the sandy material when digging or trading.

The purpose of this paper is to quantify the $\mathrm{C}$ content of both surficial and deep horizons of a typical podzol system located in the high Rio Negro basin and to extrapolate the obtained data to the whole Amazonian basin by using existing digitalized soil maps, in order to evaluate the importance of the podzol carbon reservoir at global scale.

\section{Study site and methods}

The studied area is located near the São Gabriel da Cachoeira city, Amazonia State, Brazil, at $0^{\circ} 6^{\prime} 35^{\prime \prime} \mathrm{S}, 66^{\circ} 54^{\prime} 10^{\prime \prime} \mathrm{W}$ (Fig. 1); it was described in a previous publication (Montes et al., 2007). The giant podzols area has developed from a plateau centre at the expense of reddish yellow, low activity clay ferralsols; processes and dynamics of such systems are described elsewhere (Lucas et al., 1996; Cornu et al., 1998; Lucas, 2001). The soil system is typical of those observed in the Rio Negro basin (Dubroeucq and Volkoff, 1998). The climate is typically equatorial, with an annual rainfall around $3000 \mathrm{~mm}$ and without a marked dry season. The geological substratum is composed of crystalline rocks having composition varying between monzogranitic, sienogranitic and quartzomonzonitic (Dall'Agnol and Macambira, 1992).

In the bad-drained, hydromorphic podzol area the watertable is usually shallow, reaching the topsoil after heavy rains. The vegetation is a specific evergreen forest called campinarana and characterized by a high density of $20-30 \mathrm{~m}$ height trees (Anderson, 1981). The transition between hydromorphic podzols and well-drained ferralsols is characterized by better-drained podzols, forming a 100 to $200 \mathrm{~m}$ large halo which surrounds the poorly drained area. The vegetation over both ferralsols and well drained podzols is a typical lowland Amazonian evergreen forest where dominant trees height is between 30 and $55 \mathrm{~m}$. The difference of vegetation between well- and bad-drained areas is easily recognizable on remote sensing imagery (Fig. 2).

The soils were studied using a structural analysis approach (Boulet et al., 1982; Fritsch and Fitzpatrick, 1994; Delarue et al., 2009). Observations and sampling were done by hand auger drilling following a $50 \mathrm{~m}$ square grid and along various footpaths. A total of 164 profiles were studied, giving more than 500 samples. Due to the collapse of the sandy material when digging or trading, we have developed a light method for casing auger holes and drilling through collapsing E horizons and cemented Bh horizons. Auger holes were realized with an Edelman combi-type $\varnothing 7 \mathrm{~cm}$ hand auger in the vadose zone. Non-cohesive water saturated sandy material was extracted using a $\varnothing 6.3 \mathrm{~cm}$ Eijkelkamp valve bailer. The auger hole was cased with a $\emptyset 7 \mathrm{~cm}$ PVC pipe bevelled at its end, progressively pushed down to the cemented Bh where it was pressed down by force, providing sufficient sealing to prevent fast water infiltration during drilling. The cemented part of the Bh was broken using a chisel welded to the lower end of a drill string. Soil organic $\mathrm{C}$ content was determined with a Shimadzu TOC-5000 apparatus. The soil densities were calculated from relationships previously established (du Gardin et al., 2002) and checked by direct measurements by the ring method. The average carbon content calculated for each identified group of horizons is a spatially weighted average calculated by linear interpolation between the observation points. For a given group of horizons, the given error was calculated from the propagation of the $5 \%$ error on the 

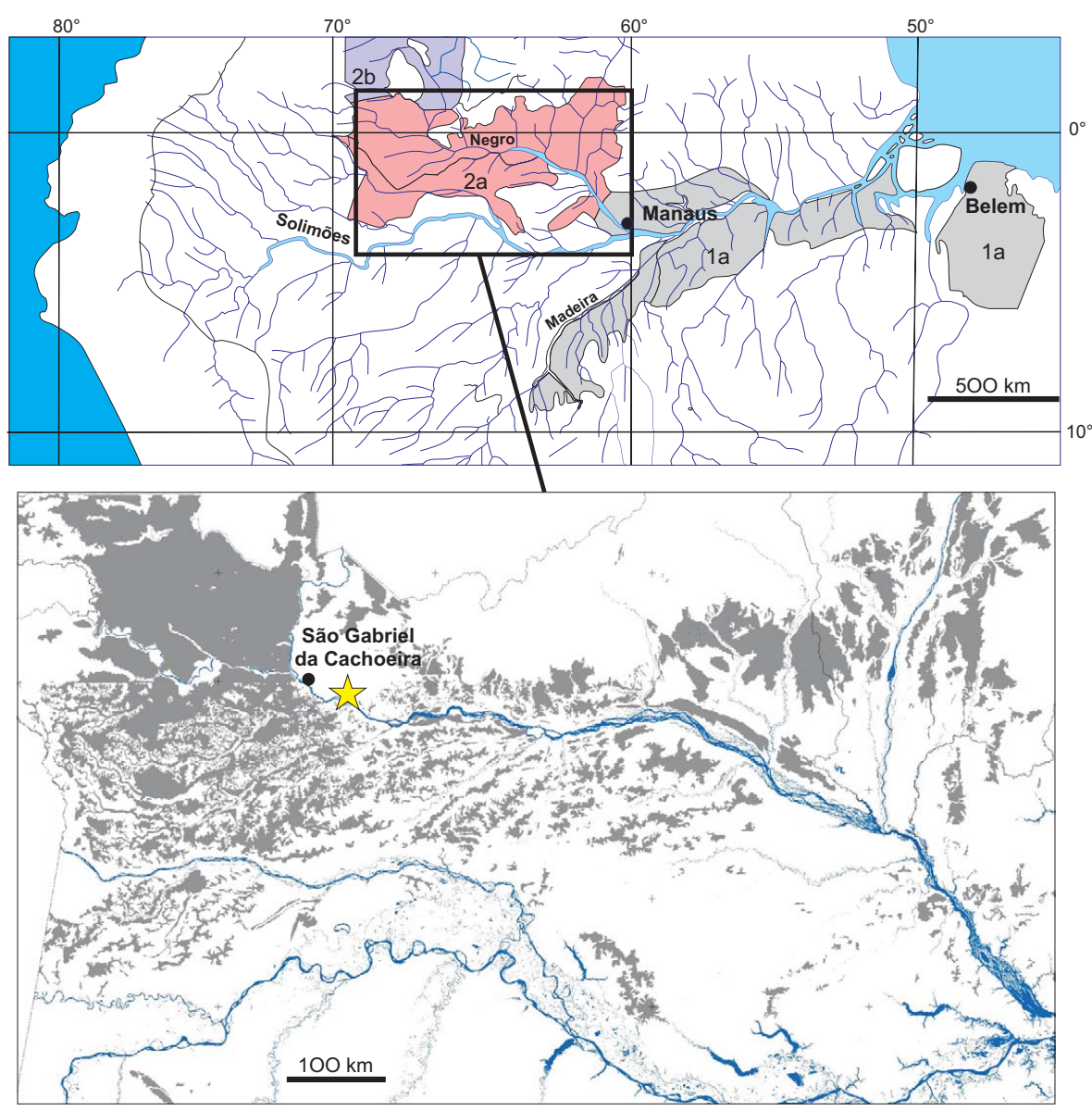

Fig. 1. Situation of the studied site (yellow star) and extension of the podzol systems in Amazonia. Coloured areas in the upper map (adapted from Martinelli et al., 1996) relate to podzol-ferralsol soil systems: 1a: clay ferralsols at the upper part of the relief units, plateau or hills, with podzols developping centripetally from the lower part of the slopes; 2a: podzols developing centrifugally from the center part of the relief units at the expense of the ferralsols; $2 b$ : systems similar to unit $2 a$, where very developed podzol areas occupy the most of a flat peneplain and ferralsol remnants are restricted to flattened hills. Grey areas in the lower map relate to hydromorphic podzol areas (adapted from IBGE, 2009).

C measurement. For extrapolation calculation, the podzol areas perimeters was calculated with a threshold-based pixel counting algorithm and the width of the better-drained halo has been set at $150 \mathrm{~m}$. Mineralogy was determined on selected samples by $\mathrm{X}$ ray diffraction on powder samples, diffuse reflectance spectroscopy and thermogravimetric analysis.

Soil water was sampled for DOC (dissolved organic carbon) analysis. Zero tension lysimeters were installed inside drilling holes at different depths, 2 points in the white sand at 20 and $150 \mathrm{~cm}$ in depth, respectively, (W-20 and W-150), one point in the Bh horizon at $230 \mathrm{~cm}$ in depth (W-240) and two points in the carbon-poor kaolin horizon beneath the Bh at $500 \mathrm{~cm}$ in depth (W-510). A spring gushing out from the center part of the podzolic area was also sampled (Spring sample). After installing the lysimeters, each drilling hole was tamped by filling with the previously extracted soil material at the corresponding depth. Each lysimeter was made of a $50 \mathrm{~mL}$ polypropylene bottle bored with $5 \mathrm{~mm}$ diameter holes all around. A $2 \mathrm{~mm}$ diameter capillary PTFE tube was inserted through the bottle cap in order to permit extracting water from the topsoil with a manual vacuum pump. To prevent clogging of the capillary tube by soil particles, a cylindrical filter made of a SeFar Nitex $64 \mu \mathrm{m}$ polyamide open mesh was put inside the bottle. Saturated groundwater samples were extracted and analyzed during three sampling periods: 27 to 30 July 2007, 29 January 2008 to 4 February 2008 and 19 to 25 May 2008. The first period was the drier and the third one the wetter. Sampling was done applying a continuous suction of $25 \mathrm{mmHg}$ during a 3 to $15 \mathrm{mn}$ period, depending on the outflow rate. The first 10 to $50 \mathrm{~mL}$ of each sampling, depending on the outflow rate, was discarded in order to avoid dead volume and to rinse the sampling equipment. Sampling was done until $250 \mathrm{~mL}$ was reached or air was entering the system. Each sample was filtered using a $0.7 \mu \mathrm{m}$ fiber glass filter, poisoned with sodium azide, stored 


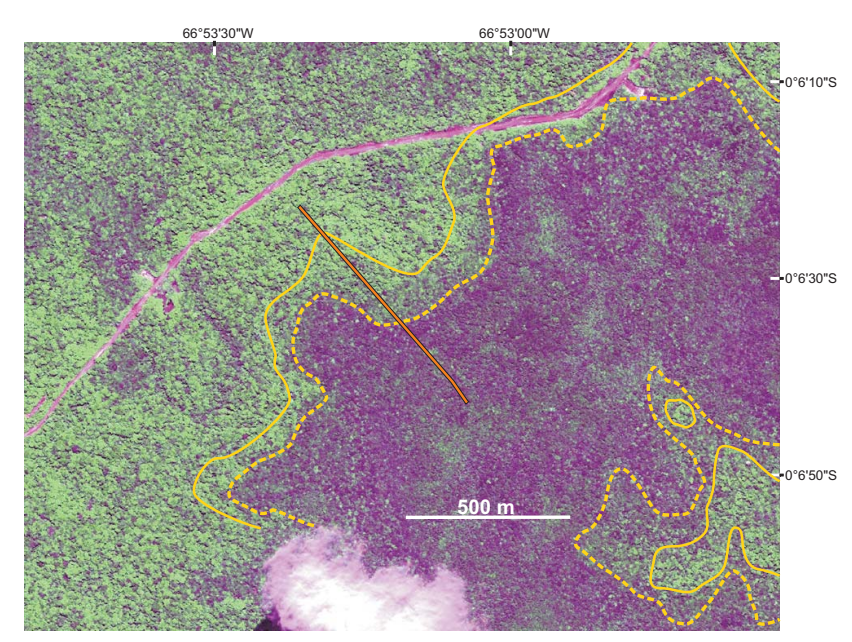

Fig. 2. View of the studied area based on Ikonos imagery. The darker green area corresponds to closed, low forest over hydromorphic podzols. The yellow line delineates the podzolic area, the yellow dotted line the bad-drained podzol area. The red line situates the sequence given in Fig. 3.

in $10 \mathrm{~mL}$ vacuum glass flasks (Vacutainer) then kept at low temperature (around $4{ }^{\circ} \mathrm{C}$ ) for laboratory DOC analysis performed with a Shimadzu TOC-5000 apparatus.

\section{Results}

\subsection{Soil features and carbon content}

Soils in the whole area are typical of old, highly weathered soil mantle. In all horizons located over the kaolinitic saprolite, residual primary minerals are quartz, heavy minerals and quite small amounts of muscovite; secondary minerals are kaolinite, gibbsite, goethite and hematite. A typical soil sequence from the edge to the centre of a podzol system is given in Fig. 3, the corresponding soil organic carbon content and horizons thickness, texture and type are given in Supplementary Fig. S1 and Table S1. Bh horizons were systematically observed at the transition between the white sand $\mathrm{E}$ horizons and the kaolinitic underlying horizons; both $\mathrm{Bh}$ thickness and carbon content are increasing when going from better-drained to poorly drained areas. At the transition between ferralsol and podzol, the Bh horizon has a thickness around 30 to $40 \mathrm{~cm}$ and overlies kaolinitic horizons (more than $83 \%$ kaolinite). When going towards the poorly drained area, the Bh progressively turns thicker, up to more than $3 \mathrm{~m}$. We divided the poorly drained podzol profiles in four groups of horizons: upper organic-rich, middle sandy, deep Bh and underlying saprolite.

The upper organic-rich horizons (O horizons) are dark (black 7.5YR2/1 to brownish black 7.5YR2/2 according to Munsell Color (2000). Their mineral fraction mainly consists of fine quartz, with small amounts of kaolinite $(<0.8 \%)$ and Ti-oxydes. They have a thickness ranging from 10 to $40 \mathrm{~cm}$, which highly depends on the local soil surface topography; the thickness is higher in slightly depressed areas where topsoil is waterlogged most of the time. Their $\mathrm{C}$ contents range from 16.8 to $178.0 \mathrm{kgC} \mathrm{m}^{-3}$, giving a total carbon content ranging from 2.5 to $41.0 \mathrm{kgC} \mathrm{m}^{-2}$ with an average of $17.0 \pm 4.0 \mathrm{kgC} \mathrm{m}^{-2}$.

The middle sandy horizons (white sand E horizons) are grey to light grey (10YR6/1 to 7/2). Their mineral fraction mainly consists of quartz sand $(>96 \%)$. They have a thickness ranging from 115 to $200 \mathrm{~cm}$ and present thin $(<4 \mathrm{~mm}$ thick) wavy black micro-horizons (thickness $<4 \mathrm{~mm}$ ). Their $\mathrm{C}$ contents range from 1.9 to $3.3 \mathrm{kgC} \mathrm{m}^{-3}$, giving a total carbon content ranging from 2.1 to $3.1 \mathrm{kgC} \mathrm{m}^{-2}$ with an average of $3.1 \pm 0.9 \mathrm{kgC} \mathrm{m}^{-2}$.

The deep $\mathrm{Bh}$ horizons have a thickness ranging from 220 to $340 \mathrm{~cm}$ and a texture varying from sandy to clayey. Their upper part, at the transition between sandy and more clayey material, is hardened over a thickness of some 20 to $40 \mathrm{~cm}$. Their colour varies from black $(7.5 \mathrm{YR} 2 / 1)$ to brown (7.5YR5/4), the upper part is usually darker and the colour turns lighter in depth. Their mineral fraction is composed of quartz sand and kaolinite in variable proportions depending on the texture, with smaller amounts of gibbsite and $\mathrm{Fe}$ (oxy)hydroxides. The material, however, is frequently heterogeneous, with darker volumes of decimetrical size. Their $\mathrm{C}$ content ranges from 3.6 to $104.1 \mathrm{kgC} \mathrm{m}^{-3}$, giving a total carbon content ranging from 50.1 to $80.9 \mathrm{kgC} \mathrm{m}^{-2}$ with an average of $66.7 \pm 5 . \mathrm{kgC} \mathrm{m}^{-2}$. The $\mathrm{C}$ content values are the highest in the top $60 \mathrm{~cm}$ of the deep $\mathrm{Bh}$ horizons and decrease in depth.

The underlying kaolinitic, saprolitic material is pale yellow to light olive gray (2.5Y8/3 to $5 \mathrm{Y} 6 / 2)$. The mineral fraction is mainly kaolinitic, with fine quartz sand and muscovite and some completely kaolinized feldspar phenocrysts. The $\mathrm{C}$ content values of the saprolitic material are lower than $1.8 \mathrm{kgC} \mathrm{m}^{-3}$.

Without considering the carbon stored in the saprolitic material, the whole podzol profiles store an average of $86.8 \pm 7.1 \mathrm{kgC} \mathrm{m}^{-2}$ for the poorly drained area and $27.9 \pm$ $2.5 \mathrm{kgC} \mathrm{m}^{-2}$ for the better drained halo.

\subsection{Soil water characteristics}

Statistics of DOC concentration in the soil and spring waters are given in Table 1. The waters from the spring and the white sand horizons (Spring, W-20 and W-150) had high DOC concentrations throughout all sampling periods, ranging from 24 to $55 \mathrm{mg} \mathrm{L}^{-1}$ with an overall average equal to $37 \mathrm{mg} \mathrm{L}^{-1}$. In the Bh horizon (W-240), the DOC concentration varied from 12 to $19 \mathrm{mg} \mathrm{L}^{-1}, 15 \mathrm{mg} \mathrm{L}^{-1}$ on average. In the deep clayey horizons (point W-510), the DOC concentrations were lower but not negligible, varying from 1.5 to $3.5 \mathrm{mg} \mathrm{L}^{-1}, 2.3 \mathrm{mg} \mathrm{L}^{-1}$ on average. 


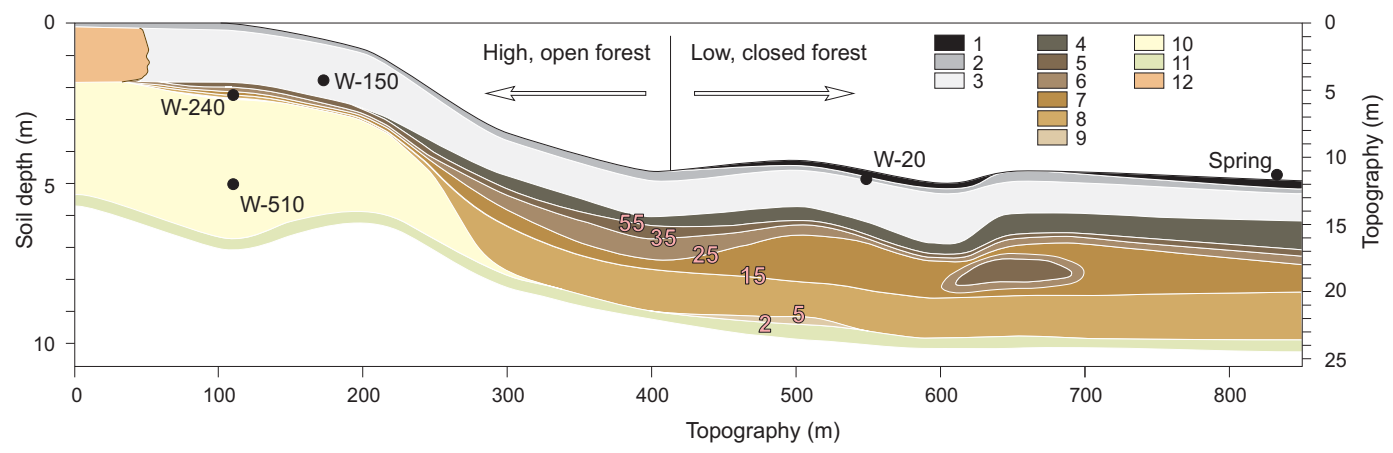

Fig. 3. A typical soil sequence from well-drained to bad-drained podzol area. 1 : upper horizons, $C>50 \mathrm{~kg} \mathrm{~m}^{-3} ; 2$ : upper horizons, $5<$ $C<50 \mathrm{~kg} \mathrm{~m}^{-3}$; 3 : white sand horizons, $2.1<C<3.4 \mathrm{~kg} \mathrm{~m}^{-3} ; 4$ to 9 : Bh horizons, $3.6<C<104.1 \mathrm{~kg} \mathrm{~m}^{-3}$ (pink numbers give $\mathrm{C}$ isolines in $\mathrm{kg} \mathrm{m}^{-3}$ ); 10 : kaolinitic horizons, $C<1.7 \mathrm{~kg} \mathrm{~m}^{-3} ; 11$ : kaolinitic saprolite, $C<2.1 \mathrm{~kg} \mathrm{~m}^{-3} ; 12$ : ferralsolic horizons, $C<1.8 \mathrm{~kg} \mathrm{~m}^{-3}$.

Table 1. DOC concentrations (in $\mathrm{m} \mathrm{L}^{-1}$ ) in the sampled waters during the three sampling periods and statistics over all periods. $\mathrm{n}$ : number of samples; av: average; sd: standard deviation; max: maximum; min: minimum.

\begin{tabular}{llll|lll|ll|ll|ll|l}
\hline & \multicolumn{4}{c}{ July 2007 } & \multicolumn{3}{c|}{ January-February 2008 } & \multicolumn{3}{c|}{ May 2008 } & \multicolumn{3}{c}{ All periods } \\
\hline & $\mathrm{n}$ & av & sd & $\mathrm{n}$ & av & sd & $\mathrm{n}$ & av & sd & av & max & $\min$ \\
\hline Spring & 3 & 38.7 & 0.3 & 4 & 42.1 & 3.4 & 4 & 31.8 & 1.9 & 37.4 & 45.4 & 29.0 \\
W-20 & 2 & 45.9 & 13.2 & 4 & 35.9 & 6.0 & 4 & 26.7 & 1.7 & 34.2 & 55.2 & 24.2 \\
W-150 & 1 & 36.5 & & 4 & 37 & 2.6 & 4 & 42.8 & 7.4 & 39.5 & 52.4 & 34.5 \\
W-240 & 4 & 14.2 & 1.6 & 4 & 16.5 & 1.9 & 4 & 13.2 & 0.7 & 14.6 & 18.9 & 12.4 \\
W-510 & 3 & 1.6 & 0.1 & & & 3 & & 3.0 & 0.4 & 2.3 & 3.5 & 1.5 & \\
\hline
\end{tabular}

\section{Discussion}

\subsection{Bh genesis}

The Bh features and the DOC values of the percolating waters confirmed the podzolic processes acting in the studied soil cover. Bh horizons underlying podzolic $\mathrm{E}$ horizons are also characteristics of boreal and temperate podzols. What is new here is the thickness and the overall $\mathrm{C}$ content of the $\mathrm{Bh}$, which indicates that unusually large quantities of DOC were transferred from the topsoil to the depth. This can be related to four main factors: (i) higher DOC concentration in the groundwater transferred from topsoil to depth, (ii) higher volumes of water transferred in depth, (iii) quality of the organic matter, with a higher resistance to mineralization, and (iv) long time of evolution.

The DOC concentration in the groundwater circulating in E horizons is of the same order of magnitude than in boreal or temperate podzols (Mossin et al., 2002; Lindroos et al., 2008).

The DOC annually produced at the topsoil and transferred in the $E$ horizons groundwater $\left(\mathrm{DOC}_{y}\right)$ is given by Eq. (1), where $P$ is the rainfall $\left(\mathrm{mm} \mathrm{y}^{-1}\right)$, ET the evapotranspiration $\left(\mathrm{mm} \mathrm{y}^{-1}\right)$ and $\mathrm{DOC}_{E}$ the DOC concentration in the white sand $E$ horizons $\left(\mathrm{mg} \mathrm{L}^{-1}\right)$ :

$\mathrm{DOC}_{y}=(P-\mathrm{ET})\left(\mathrm{DOC}_{E}\right) 10^{-3}$

The present-day values of the parameters of the second member of this equation can be estimated from the literature and the present study: $3000 \mathrm{~mm} \mathrm{y}^{-1}$ for $P$ (Silva et al., 1977), $1500 \mathrm{~mm} \mathrm{y}^{-1}$ for ET (Leopoldo et al., 1987) and $37 \mathrm{mg} \mathrm{L}^{-1}$ for $\mathrm{DOC}_{E}$ (this study). Using these values, $\mathrm{DOC}_{y}$ is $55.5 \mathrm{~g} \mathrm{~m}^{-2} \mathrm{y}^{-1}$, which is more than 10 time higher than the DOC transferred at $40 \mathrm{~cm}$ in depth in boreal podzols (Lindroos et al., 2008). This higher value is mainly linked to higher annual rainfall.

The DOC annually transferred and retained in the $\mathrm{Bh}$ $\left(\mathrm{OM}_{y}\right.$, in $\left.\mathrm{gC} \mathrm{m}^{-2} \mathrm{y}^{-1}\right)$ is given by Eq. (2), where $\mathrm{DOC}_{S}$ is the DOC concentration in the saprolite $\left(\mathrm{mg} \mathrm{L}^{-1}\right)$ and $r_{d p}$ the ratio of non-evapotranspired water entering the saprolite, which corresponds to the baseflow:

$\mathrm{OM}_{y}=(P-\mathrm{ET})\left(\mathrm{DOC}_{E}-\mathrm{DOC}_{S}\right) r_{d p} 10^{-3}$

From this study, $\mathrm{DOC}_{S}$ can be estimated as $2.3 \mathrm{mg} \mathrm{L}^{-1}$. The value of $r_{d p}$ is more difficult to evaluate. Tardy et al. (2009) calculated 0.216 and 0.193 for the Rio Negro and the Rio Jutaí basins, respectively. Since there are no podzol systems in the watershed of the latter, that the slope index of 
the Rio Jutaí basin is close to the one of Rio Negro and that the hydromorphic podzols occupy $21 \%$ of the Rio Negro watershed, we calculated 0.303 for $r_{d p}$ in the podzol area, which corresponds to $455 \mathrm{~mm}$ of groundwater percolating annually through the $\mathrm{Bh}$. Using these values, $\mathrm{OM}_{y}$ is $16.8 \mathrm{gC} \mathrm{m}^{-2} \mathrm{y}^{-1}$. With the hypothesis that the organic matter retained in the Bh horizons does not suffer any posterior mineralization, it would last 4044 y to accumulate the average $68 \mathrm{kgC} \mathrm{m}^{-2}$ nowadays observed in the deep Bh. Such a value is evidently lower than the actual value, because part of the adsorbed organic matter is likely to be lost due to mineralization. A Bh genesis model thus must consider one or more mineralization rates. Those are still unknown and need further investigations, but to give an order of magnitude the calculation was performed using a single type organic matter, a first order mineralization reaction and a rate constant equal to $2.510^{-4} \mathrm{y}^{-1}$, calculated by considering $2800 \mathrm{y}$ as the half-life of Bh organic matter. This half-life was chosen in order to obtain an average age for the Bh organic-matter around $2000 \mathrm{y}$, in coherence with the few existing Amazonian Bh datations (Bravard and Righi, 1990). Which such hypothesis, it would last $30 \mathrm{ky}$ to accumulate $68 \mathrm{kgC} \mathrm{m}^{-2}$ in a Bh under the present day conditions.

\subsection{Extrapolation to the Amazonian basin}

The deep carbon, as well as most of the carbon stored in the organic-rich upper horizons, was not considered in studies dealing with the quantification of Amazonian soil carbon (Batjes and Dijkshoorn, 1999; Bernoux et al., 2002; Cerri et al., 2007). Nevertheless, wherever a detailed study of Amazonian podzols has been achieved, the presence of deep Bh has been attested, so we may assume deep carbon storage in every podzol area. The quantification we made from a single area must obviously be refined throughout Amazonia and moreover throughout other equatorial podzol areas, particularly in the Kalimantan (Brabant, 1987), in Congo (Schwartz, 1988) and in Zambia (Brammer, 1973). Extrapolation of our data across Amazonia can, however, give an order of magnitude of the carbon stored in Amazonian podzols.

Existing IBGE digitalized soil maps of Amazonia (IBGE, 2009) were made mainly from radar surveys (RADAMBRASIL, 1978) quite sensitive to the physical characteristics of roughness, slope and moisture on the soil surface, so that the large flat, poorly-drained podzols areas have been identified with certainty. The poorly drained podzol area we calculated from IBGE maps is $1554105 \mathrm{~km}^{2}$ (lower map of Fig. 1). Extrapolating the data of our detailed study, we calculated the carbon stored in the Amazonian podzols to be $13.6 \pm 1.1 \mathrm{PgC}$, more than $12.3 \mathrm{PgC}$ higher than previous estimates ( $1 \mathrm{PgC}$ for the topsoil $0-30 \mathrm{~cm}$ after Batjes and Dijkshoorn, 1999 or $1.3 \mathrm{PgC}$ for the topsoil 0-1 m after Bernoux et al., 2002). This calculated value is certainly an underestimate, given that soil systems that include podzols, but where podzols are fragmented into small areas that do not appear in digitalized soil maps, cover areas around $8105 \mathrm{~km}^{2}$ as calculated from RADAM maps (unit 1a on Fig. 1) .

In comparison, the total amount of carbon stored in the aerial biomass of the Amazonian forest was estimated as $93 \pm 23 \mathrm{PgC}$ (Malhi et al., 2006).

\subsection{Lability of the podzol organic matter}

Is the carbon stored in the deep Bh likely to quickly return to the atmosphere if the climate changes? Most podzol areas are situated in the high Rio Negro basin. For this area, 18 different global warming climate models give projections on both precipitation and soil moisture (Meehl et al., 2007). All of those predict an increase of the average air temperature, seven a diminution of the annual precipitation, ten a diminution of the average soil moisture and eight an increase of contrast between the wet and dry seasons. Consecutive changes of temperature and dynamics of the water-table could destabilize the organic matter of the upper horizons as well as of the deep, resulting in a complete or partial mineralization. In temperate podzols, organic horizons with relatively short turnover times could be particularly vulnerable to changes in climate or other disturbances (Schulze and al., 2009). Deep Bh from the Manaus area gave two apparent ${ }^{14} \mathrm{C}$ ages, $490 \pm 90$ and $2840 \pm 90$ y BP (Bravard and Righi, 1990), which is young when considering the potential age of the podzols. Some tropical podzols from Congo that were formed in the past and which are nowadays under a drier climate keep up thick deep Bh apparently rich in organic matter (Schwartz, 1988), but there is no comparison available between still hydromorphic and currently well-drained podzols.

As it is difficult to conclude about the sensibility of the deep Bh organic matter to climate change, some complementary studies similar to those realized for northern peatland organic matter (Dorrepaal et al., 2009) are needed to evaluate the feedback between the podzols carbon cycle and climate.

\section{Conclusions}

The studied hydromorphic podzols from the high Rio Negro exhibited thick Bh horizons at depth. The carbon stored in the podzols was on average $66.7 \pm 5.8 \mathrm{kgC} \mathrm{m}^{-2}$ for the deep $\mathrm{Bh}$ and $86.8 \pm 7.1 \mathrm{kgC} \mathrm{m}^{-2}$ for the whole profile. The genesis of the deep Bh is likely due to high volumes of DOC-rich groundwater percolating in depth as well as a sufficient time of evolution and a sufficient stability of the adsorbed OM. As the OM saturates the minerals exchange sites, the dissolved organic matter is able to percolate more in depth, resulting in an increase of the Bh thickness. The dynamics of Bh formation, however, need to be better assessed.

Extrapolation of the obtained results to the whole Amazonia gave $13.6 \pm 1.1 \mathrm{PgC}$ for the carbon stored in hydromorphic podzols, which is at least $12.3 \mathrm{PgC}$ higher than previous 
estimates. This value is likely an underestimate, because soil systems where podzols are fragmented into small areas were not taken in account in the quantification. This quantification has thus to be refined by additional investigations, not only in Amazonia but in all equatorial areas where podzols have been identified.

Considering the volume of carbon stored in the podzol $\mathrm{Bh}$, the stability of the Bh organic matter in a context of climate change needs to be assessed. Because of the lack of knowledge on the quality and behaviour of the podzol organic matter, the question of the feedback between the climate and the equatorial podzol carbon cycle is open.

\section{Supplementary material related to this article is available online at: http://www.biogeosciences.net/8/113/2011/ bg-8-113-2011-supplement.pdf.}

Acknowledgements. This work was funded by grants from Brazilian FAPESP and CNPq, French-Brazilian CAPES-COFECUB exchange program and French ARCUS (joint program from Région PACA and French Ministry of Foreign Affairs).

Edited by: S. Bouillon

\section{References}

Anderson, A. B.: White-sand vegetation of Brazilian Amazonia, Biotropica, 13, 199-210, 1981.

Bardy, M., Bonhomme, C., Fritsch, E., Maquet, J., Hajjar, R., Allard, T., Derenne, S., and Calas, G.: Al speciation in tropical podzols of the upper Amazon Basin: A solid-state 27Al MAS and MQMAS NMR study, Geochim. Cosmochim. Ac., 71, 32113222, 2007.

Bardy, M., Fritsch, E., Derenne, S., Allard, T., do Nascimento, N. R., and Bueno, G. T.: Micromorphology and spectroscopic characteristics of organic matter in waterlogged podzols of the upper Amazon basin, Geoderma, 145, 222-230, 2008.

Batjes, N. H. and Dijkshoorn, J. A.: Carbon and nitrogen stocks in the soils of the Amazon Region, Geoderma, 89, 273-286, 1999.

Bernoux, M., Carvalho, M. C. S., Volkoff, B., and Cerri, C. C.: Brazil's soil carbon stocks, Soil Sci. Soc. Am. J., 66, 888-896, 2002.

Boulet, R., Chauvel, A., Humbel, F. X., and Lucas, Y.: Analyse structurale et cartographie en pédologie. I- Prise en compte de l'organisation bidimensionnelle de la couverture pédologique: les études de toposéquences et leurs principaux apports à la connaissance des sols, Cah. ORSTOM, sér. Pédol, XIX, 309-321, 1982.

Brabant, P.: La répartition des podzols à Kalimantan (Ile de Bornéo), in: Podzols et Podzolisation, INRA, Paris, 13-24, 1987.

Brammer, H: Podzols in Zambia, Geoderma, 10, 249-260, 1973.

Bravard, S. and Righi, D.: Geochemical differences in an oxisolspodosol toposequence of Amazonia (Brazil), Geoderma, 44, 29-42, 1989.

Bravard, S. and Righi, D.: Podzols in Amazonia, Catena, 17, 461$475,1990$.
Cerri, C. E. P., Easter, M., Paustian, K., Killian, K., Coleman, K., Bernoux, M., Falloon, P., Powlson, D. S., Batjes, N. H., Milne,E., and Cerri,C. C.: Predicted soil organic carbon stocks and changes in the Brazilian Amazon between 2000 and 2030, Agric. Ecosyst. Environ., 122, 58-72, 2007.

Chauvel , A., Lucas, Y., and Boulet, R.: On the genesis of the soil mantle of the region of Manaus, Central Amazonia, Brazil, Experientia, 43, 234-241, 1987.

Cornu, S., Lucas, Y., Ambrosi, J. P., and Desjardins, T.: Transfer of dissolved $\mathrm{Al}, \mathrm{Fe}$ and $\mathrm{Si}$ in two amazonian forest environment in Brazil. Eur. J. Soil Sci., 49, 377-384, 1998.

Dall'Agnol, R. and Macambira, M. J. B.: Titanita biotita granitos do baixo Rio Uaupés, Provncia Rio Negro, Amazonas. Parte 1: Geologia, petrografia e geocronologia. Rev. Bras. Geocienc., 22, 3-14, 1992.

Davis, J. A.: Adsorption of natural dissolved organic matter at the oxide/water interface, Geochim. Cosmochim. Acta, 46, 23812393, 1982.

Delarue, F., Cornu, S., Daroussin, J., Salvador-Blanes, S., Bourennane, H., Albric, P., Vennink, A., Bruand, A., and King, D.: 3-D representation of soil distribution: An approach for understanding pedogenesis, Comptes Rendus Geosciences, 341, 486-494, 2009

Dorrepaal, E., Toet, S., van Logtestijn, R. S. P., Swart, E., van de Weg, M. J., Callaghan, T. V., and Aerts, R.: Carbon respiration from subsurface peat accelerated by climate warming in the subarctic, Nature, 460, 616-619, 2009.

Dubroeucq, D. and Volkoff, B.: Evolution des couvertures pédologiques sableuses à podzols géants d'Amazonie (Bassin du Haut Rio Negro), Cah. ORSTOM, sér. Pédol., 24, 191-214, 1988.

Dubroeucq, D., Volkoff, B., and Pédro, G.: La couverture pédologique du Bouclier du Nord de l'Amazonie (bassin du Haut Rio Negro), Séquence évolutive des sols et son rôle dans l'aplanissement généralisé des zones tropicales perhumides, $\mathrm{C}$. R. Acad. Sci., Paris, Ser. IIA, 312, 663-671, 1991.

Dubroeucq, D. and Volkoff, B.: From oxisols to spodosols and histosols: evolution of the soil mantles in the Rio Negro Basin (Amazonia), Catena, 32, 245-280, 1998.

Fritsch, E. and Fitzpatrick, R. W.: Interpretation of soil features produced by ancient and modern processes in degraded landscapes, I, A new method for constructing conceptual soil-waterlandscape models, Austr. J. Soil Res., 32, 889-907, 1994.

Fritsch, E., Allard, T., Benedetti, M. F., Bardy, M., do Nascimento, N. R., Li, Y., and Calas, G.: Organic complexation and translocation of ferric iron in podzols of the Negro River watershed. Separation of secondary Fe species from Al species, Geochim. Cosmochim. Acta, 73, 1813-1825, 2009.

du Gardin, B., Grimaldi, M., and Lucas, Y.: Effets de la déshydratation sur les sols du système ferralsol-podzols d'Amazonie centrale. Reconstitution de la courbe de désorption d'eau à partir de la porosimétrie au mercure, Bull. Soc. Géol. France, 173, 19-34, 2002.

Grimaldi, C. and Pedro, G.: Importance de l'hydrolyse acide dans les systèmes pédologiques des régions tropicales humides. Rôle de la forêt et conséquences sur la genèse des sables blancs tropicaux, C. R. Acad. Sci. Ser. lla, 323, 483-492, 1996.

Horbe, A. M. C., Horbe, M. A., and Suguio, K.: Tropical Spodosols in northeastern Amazonas State, Brazil, Geoderma, 119, 55-68, 
2004.

IBGE: Levantamento pedológico, folhas NA-19, NA-20, SA-19 e SA-20, CREN-IBGE, São Paulo, 2009.

Kaiser, K. and Zech, W.: Dissolved organic matter sorption by mineral constituents of subsoil clay fractions, J. Plant Nutr. Soil Sci., 163, 531-535, 2000.

Leopoldo, P. R., Franken, W., Salati, E., and Ribeiro, M. N.: Toward a water balance in the Central Amazonian region, Experientia, 43, 222-233, 1987.

Lindroos, A. J., Derome, J., Mustajärvi, K., Nöjd, P., Beuker, E., and Helmisaari, H. S.: Fluxes of dissolved organic carbon in stand throughfall and percolation water in 12 boreal coniferous stands on mineral soils in Finland, Boreal Environment Research 13, Suppl. B, 22-34, 2008.

Lucas, Y.: The role of the plants in controlling rates and products of weathering: importance of the biological pumping, Ann. Rev. Earth Planet. Sci., 29, 135-163, 2001.

Lucas, Y., Chauvel, A., Boulet, R., Ranzani, G., and Scatolini, F.: Transição latossolos-podzois sobre a formação Barreiras na região de Manaus, Amazônia, Rev. Bras. Cienc. Solo 8, 325335, 1984

Lucas, Y., Boulet, R., and Chauvel, A.: Intervention simultanée des phénomènes d'enfoncement vertical et de transformation latérale dans la mise en place de systèmes de sols de la zone tropicale humide. Cas des systèmes sols ferrallitiques - podzols de l'Amazonie Brésilienne, C. R. Acad. Sci. Paris, Ser. 1la, 306, 1395-1400, 1988.

Lucas, Y. and Chauvel, A.: Soil formation in tropically weathered terrains, in: Regolith exploration geochemistry in tropical and subtropical terrains, edited by: C. R. M. Butt and H. Zeegers, Elsevier, Amsterdam - London - New-York - Tokyo, 57-77, 1992.

Lucas, Y., Nahon, D., Cornu, S., and Eyrolle, F.: Genèse et fonctionnement des sols en milieu équatorial, C . R. Acad. Sci. Paris Ser. IIa, 322, 1-16, 1996.

Malhi, Y., Roberts, J. T., Betts, R. A., Killeen, T. J., Li, W., and Nobre, C. A.: The regional variation of aboveground live biomass in old-growth Amazonian forests, Glob. Change Biol., 12, 11071138, 2006.

Martinelli, L. A., Lucas, Y., Cerri, C. C., and Victoria, R. L.: Os solos da Amazonia: distribuição e alterações pelo uso da terra, in: Conferência Internacional Uma Estrategia Latino-Americana para a Amazonia, Editora USP, São Paulo, 209-226, 1996.

Meehl, G. A., Stocker, T. F., Collins, W. D., Friedlingstein, P., Gaye, A. T., Gregory, J. M., Kitoh, A., Knutti, R., Murphy, J. M., Noda, A., Raper, S. C. B., Watterson, I. G., Weaver, A. J., and Zhao, Z. C.: in: Climate Change 2007: The Physical Science Basis, edited by: Solomon, S., Qin, D., Manning, M., Chen, Z., Marquis, M., Averyt, K. B., Tignor, M., and Miller, H. L., Cambridge University Press, 2007.
Montes, C. R., Lucas, Y., Melfi, A. J., and Ishida, D. A.: Systèmes sols ferrallitiques-podzols et genèse des kaolins, C. R. Geosci., 339, 50-56, 2007.

Mossin, L., Mortensen, M., and Nørnberg, P.: Imogolite related to podzolization processes in Danish podzols, Geoderma, 109, 103-116, 2002.

Munsell Color: Munsell soil color charts, revised edition, Munsell Color/GretagMacBeth, New York, 2000.

Nascimento, N. R., Bueno, G. T., Fritsch, E., Herbillon, A. J., Allard, T., Melfi, A., Astolfo, R., Boucher, H., and Li, Y.: Podzolization as a deferralitization process: a study of an AcrisolPodzol sequence derived from Palaeozoic sandstones in the northern upper Amazon Basin, Eur. J. Soil Sci., 55, 523-538, 2004.

Patel-Sorrentino, N., Lucas, Y., Eyrolles, F., and Melfi, A. J.: Fe, $\mathrm{Al}$ and Si species and organic matter leached off a ferrallitic and podzolic soil system from Central Amazonia, Geoderma, 137, 444-454, 2007.

RADAMBRASIL: Levantamento de Recursos Naturais, 18, Ministério de Minas e Energia, Rio de Janeiro, 623 pp., 1978.

Richards, P. W.: Lowland tropical podzols and their vegetation, Nature, 148, 129-131, 1941.

Righi, D., Bravard, S., Chauvel, A., Ranger, J., and Robert, M.: In situ study of soil processes in an oxisol-spodosol sequence of Amazonia (Brazil), Soil Sci., 150, 438-445, 1990.

Schulze, K., Borken, W., Muhr, J., and Matzner, E.: Stock, turnover time and accumulation of organic matter in bulk and density fractions of a Podzol soil, Eur. J. Soil Sci., 60, 567-577, 2009.

Schwartz, D.: Some podzols on Bateke sands and their origins, People's Republic of Congo, Geoderma, 43, 229-247, 1988.

Silva, F. C. F., Jesus, R. M., and Ribeiro, A. G.: Vegetação, in: Projeto RADAM BRASIL, Folha SA. 19 Içá, Levantamento de Recursos Naturais 14, Ministério de Minas e Energia, Rio de Janeiro, 297-396, 1977.

Tardy, Y., Roquin, C., Bustillo, V., Moreira, M., Martinelli, L. A., and Victoria, R.: Carbon and Water Cycles Amazon River Basin Applied Biogeochemistry, Atlantica, Biarritz, 2009.

Veillon, L.: Sols ferrallitiques et podzols en Guyane Septentrionale. Relations entre systèmes de transformations pédologiques et évolution historique d'un milieu tropical humide et forestier, Travaux et Documents Microfilmés, 76, ORSTOM, Paris, 266 pp., 1991.

Veillon, L. and Soria-Solano, B.: Transition sol ferrallitique - podzol: cas d'une terrasse sédimentaire de l'Ucayali (Perou), Cah. ORSTOM, sér. Pédol., 24, 97-113, 1988.

Volkoff, B., Mortatti, J., and Cerri, C. C.: Rôle des nappes dans les différenciations pédologiques des zones à podzols de l'Amazonie, C . R. Acad. Sci. Ser. IIa, 310, 1361-1368, 1990. 